\title{
EFFECT OF COOLING RATE ON THE SHAPE MEMORY BEHAVIOR OF Ti-54at.\% Ni ALLOYS
}

\author{
İrfan KAYA * \\ Department of Mechanical Engineering, Faculty of Engineering, Anadolu University, 26555 Eskişehir, Turkey
}

\begin{abstract}
The effects of cooling rate after aging at $550{ }^{\circ} \mathrm{C}$ for $3 \mathrm{~h}$ on the shape memory behavior and mechanical properties of Ti$54 \mathrm{at} . \% \mathrm{Ni}$ alloys are investigated in compression. It was found that it is possible to tailor the transformation temperatures of Ti54at.\% Ni alloys with cooling rate where multiple step transformation can also be observed. Shape memory behavior with transformation strain of $1 \%$ is observed under ultra high stress level of $1500 \mathrm{MPa}$. It is also found that shape memory effect is highly stress dependent.
\end{abstract}

Keywords: Ni-rich NiTi shape memory alloy, Cooling rate effect, Thermomechanical loading, Multiple step transformation, R-Phase transformation

\section{INTRODUCTION}

Nickel rich NiTi alloys are considered to be the most widely used shape memory alloys (SMAs) in many industries including aerospace, automotive, bio-medical, and construction due to their distinct shape memory and superelasticity properties [1-4]. The martensitic transformation of NiTi SMAs has been discussed in many studies [5,6]. The high temperature phase of NiTi is austenite with the B2 structure, and the low temperature phase is martensite with the B19' structure [7, 8]. The single step martensite transformation can be changed to multiple step transformation by the heat treatment due to the precipitates formation. In multiple step transformation, the first transformation is B2 to R-phase; further cooling then transforms the resulting R-phase to B19' [9, 10]. R-phase transformation temperatures are very stable and independent of thermomechanical treatments [11].

Nishida and Kainuma reported that the precipitation properties depend on cooling rate, aging time and aging temperature [12-14]. The decrease of cooling rate leads to the formation of Ni4Ti3 and Ni3Ti precipitates, which decrease the Ni concentration of the matrix. The transformation temperatures of NiTi alloy decrease with increasing Ni content of matrix [2]. The presence of precipitates provides R-phase formation in NiTi SMAs. Ni-rich NiTi alloys show multiple step martensitic transformations associated with this intermediate R-phase $[15,16]$.

In this study, cooling rate effect on the shape memory properties of Ti-54at.\%Ni alloys were studied. Systematic shape memory effect tests as a function of stress and superelasticity tests as a function of temperature were conducted under compressive stress. The effects of cooling rate after aging at $550{ }^{\circ} \mathrm{C}$ on the strain and hysteresis, the transformation temperatures, and R-phase formation were investigated. 


\section{MATERIALS AND METHODS}

The Ti-54at.\%Ni ingots were homogenized at $1000^{\circ} \mathrm{C}$ for $4 \mathrm{~h}$ in argon atmosphere in evacuated quartz tubes, followed by quenching into water. After homogenization, they were aged at $550{ }^{\circ} \mathrm{C}$ for $3 \mathrm{~h}$ which were selected to produce precipitates in the material to alter shape memory properties. Aged SMAs were cooled down by three methods; water quenching (WQ), air cooling (AC), and furnace cooling (FC) where $2{ }^{\circ} \mathrm{C} \mathrm{min}{ }^{-1}$ cooling rate was applied for furnace cool.

Transformation temperatures (TT) of the transformation were determined by Perkin Elmer 1 differential scanning calorimetry (DSC). The specimens of about $30 \mathrm{mg}$ in weight were cut from the aged samples, and put in Al pans. The DSC measurements were made with a cooling and heating rate of $10{ }^{\circ} \mathrm{C} \mathrm{min}-1$ in helium atmosphere. The microstructure was investigated by transmission electron microscopy (TEM, JEOL JEM-2100HR). The thin foil specimens for TEM were prepared by a twin-jet electropolishing device in a solution consisting of (all vol\%) $8 \%$ perchloric acid, $72 \%$ acetic acid, $12 \%$ methanol and $8 \%$ ethylene glycol at room temperature. TEM observations were carried out by TEM operated at an acceleration voltage of $200 \mathrm{kV}$. Compression testing of Ti-54at.\% $\mathrm{Ni}$ was done on $4 \times 4 \times 8 \mathrm{~mm}^{3}$ samples that were cut by electro discharge machine. The compression tests were performed at the MTS Landmark servo-hydraulic load frame with $100 \mathrm{kN}$ MTS load cell. Strain was measured using MTS high temperature extensometer with a $12 \mathrm{~mm}$ gage length. The temperature of sample was measured by K-type thermocouple attached on the center of the sample and also compression grips. Strain rate was $10^{-4} / \mathrm{s}$ and heating rate was $10^{\circ} \mathrm{C} \mathrm{min}{ }^{-1}$ while cooling rate was $5{ }^{\circ} \mathrm{C} \mathrm{min}{ }^{-1}$. An Omega $\mathrm{CN} 8200$ series temperature controller was used to control the temperature rate.

\section{RESULTS AND DISCUSSION}

\subsection{DSC and TEM}

Figure 1a shows the DSC results of homogenized and aged Ti-54at.\%Ni samples. In order to determine the effects of cooling rate, the samples were aged at $550{ }^{\circ} \mathrm{C}$ for $3 \mathrm{~h}$ and then cooled down by WQ, AC and FC methods. In Figure 1a, no peaks were observed for the homogenized sample. Austenite finish temperature $\left(\mathrm{A}_{\mathrm{f}}\right)$ and martensite finish temperature $\left(\mathrm{M}_{\mathrm{f}}\right)$ obtained from Figure 1a are given in Table 1 . The decrease in cooling rate after $550{ }^{\circ} \mathrm{C}$ aging increased the TTs. TEM results were shown in Figure $1 \mathrm{~b}$ and $1 \mathrm{c}$ for $550^{\circ} \mathrm{C}-\mathrm{WQ}$ sample and $550^{\circ} \mathrm{C}-\mathrm{FC}$ sample respectively. The obvious difference in microstructure was the only size of precipitate observed by TEM images. The FC sample had larger precipitates than WQ sample. It can be argued that the decrease in cooling rate promoted the formation of Ni-rich Ni4Ti3 precipitates, which in turn decreased the Ni concentration of the matrix [12]. Since the TTs of Ni-rich NiTi alloys decrease with increasing Ni content of matrix, lower nickel content of the matrix after $550^{\circ} \mathrm{C}$-FC samples resulted in an increase in TTs [17]. In $550^{\circ} \mathrm{C}$-FC, the first peak during cooling at about $40{ }^{\circ} \mathrm{C}$ was attributed to the R-phase formation. The other two peaks during cooling can be attributed to the B19' martensite formation due to inhomogeneity in microstructure [18]. 


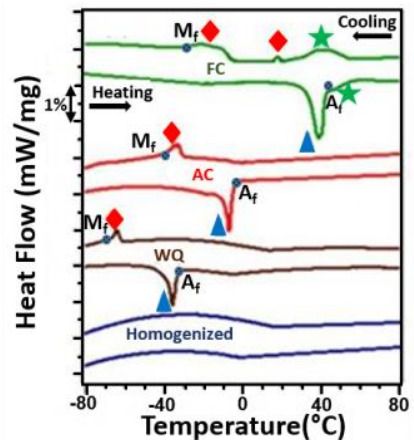

$\triangle \mathrm{A}$ peak $\rightarrow \mathrm{M}$ peak $\star \mathrm{R}$ peak

(a)

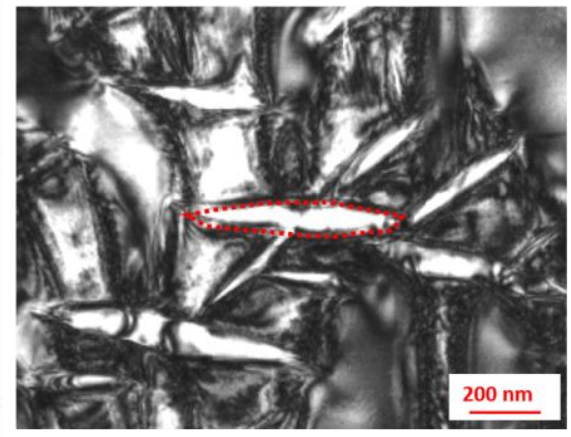

(b)

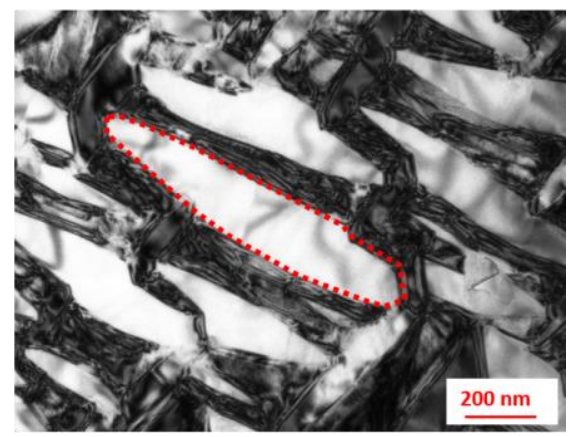

(c)

Figure 1. a) DSC curves of the Ti-54at. $\% \mathrm{Ni}$ alloy aged $550^{\circ} \mathrm{C}$. The chart shows the cooling effect on the martensitic transformation. b) TEM micrograph of WQ sample and c) TEM micrograph of FC sample

The $\mathrm{A}_{\mathrm{f}}$ of $\mathrm{FC}, \mathrm{AC}$ and WQ samples were $57^{\circ} \mathrm{C},-4^{\circ} \mathrm{C}$ and $-33^{\circ} \mathrm{C}$, respectively. The cooling rate affects the thermal hysteresis. It was seen that hysteresis $\left(\mathrm{A}_{\mathrm{f}}-\mathrm{M}_{\mathrm{f}}\right)$ increased with decreased cooling rate (Table 1). The highest hysteresis of $86^{\circ} \mathrm{C}\left(\mathrm{A}_{\mathrm{f}}-\mathrm{M}_{\mathrm{f}}\right)$ was observed with the lowest cooling rate that is the $\mathrm{FC}$ sample.

Table 1. Phase transformation temperatures of $550^{\circ} \mathrm{C}$ aged samples

\begin{tabular}{cccc}
\hline Sample & $\mathbf{A}_{\mathbf{f}}\left({ }^{\circ} \mathbf{C}\right)$ & $\mathbf{M}_{\mathbf{f}}\left({ }^{\circ} \mathbf{C}\right)$ & $\mathbf{A}_{\mathbf{f}}-\mathbf{M}_{\mathbf{f}}\left({ }^{\circ} \mathbf{C}\right)$ \\
\hline WQ & -33 & -66 & 33 \\
AC & -4 & -38 & 34 \\
FC & 57 & -29 & 86 \\
\hline
\end{tabular}

\subsection{Compression Test}

Figure 2 shows the thermal cycling under stress curves of $550^{\circ} \mathrm{C}$-WQ and $550^{\circ} \mathrm{C}$-FC samples. Selected compressive stresses were applied in austenite and the specimens were cooled down below $\mathrm{M}_{\mathrm{f}}$. Then, it was heated above the $\mathrm{A}_{\mathrm{f}}$ to complete the cycle under the applied constant compressive stress. In Figure 2 , the transformation strain increased with stress. While transformation strain was $0.29 \%$ under 200 $\mathrm{MPa}$, it increased to $0.86 \%$ under $1000 \mathrm{MPa}$ for $550^{\circ} \mathrm{C}-\mathrm{WQ}$. Although very close transformation strains were detected at low stress levels, lower transformation strain $(0.78 \%)$ was obtained at high stress level (under $1000 \mathrm{MPa}$ ) for $550^{\circ} \mathrm{C}-\mathrm{FC}$ [19]. The TTs increased with stress in both cases. $\mathrm{M}_{\mathrm{s}}$ (martensite start temperature) and $\mathrm{A}_{\mathrm{f}}$ were $-37^{\circ} \mathrm{C}$ and $-22{ }^{\circ} \mathrm{C}$ under $400 \mathrm{MPa}$ while they increased to $20^{\circ} \mathrm{C}$ and $35^{\circ} \mathrm{C}$ under $1000 \mathrm{MPa}$ for $550^{\circ} \mathrm{C}$-WQ sample. $\mathrm{M}_{\mathrm{s}}$ and $\mathrm{A}_{\mathrm{f}}$ were $51^{\circ} \mathrm{C}$ and $58{ }^{\circ} \mathrm{C}$ under $400 \mathrm{MPa}$ while they increased to $89{ }^{\circ} \mathrm{C}$ and $94{ }^{\circ} \mathrm{C}$ under $1000 \mathrm{MPa}$ for $550^{\circ} \mathrm{C}$-FC sample. The thermal hysteresis was determined as the midpoint of the transformation strain between the cooling and heating curves. The thermal hysteresis was substantially decreased with stress. For $550^{\circ} \mathrm{C}-\mathrm{WQ}$, the thermal hysteresis was $25^{\circ} \mathrm{C}$ under $200 \mathrm{MPa}$ and $18{ }^{\circ} \mathrm{C}$ under $1000 \mathrm{MPa}$. Thermal hysteresis of $550^{\circ} \mathrm{C}$-WQ was higher than the thermal hysteresis of $550^{\circ} \mathrm{C}$-FC under all stress levels but $1500 \mathrm{MPa}$. The high irrecoverable strain of $550^{\circ} \mathrm{C}-\mathrm{FC}$ sample under $1500 \mathrm{MPa}$ is responsible for the high temperature hysteresis.

Irrecoverable strain was found to be higher for the FC sample at $1500 \mathrm{MPa}$ stress level. The irrecoverable strain of FC and WQ samples were $0.32 \%$ and $0.23 \%$, respectively, at $1500 \mathrm{MPa}$. Additionally, increasing stress from $1000 \mathrm{MPa}$ to $1500 \mathrm{MPa}$ elevated the irrecoverable strain from $0.08 \%$ to $0.23 \%$ for $550^{\circ} \mathrm{C}-\mathrm{WQ}$ and from $0.09 \%$ to $0.32 \%$ for $550^{\circ} \mathrm{C}-\mathrm{FC}$ samples. 


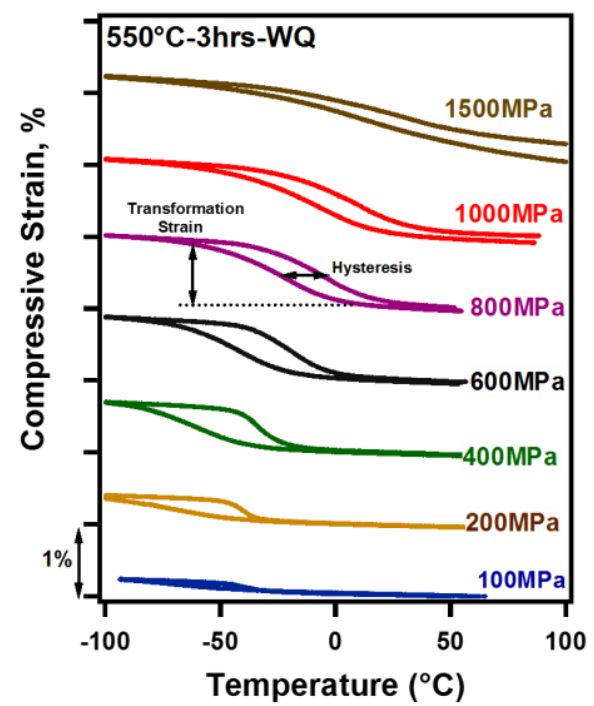

(a)

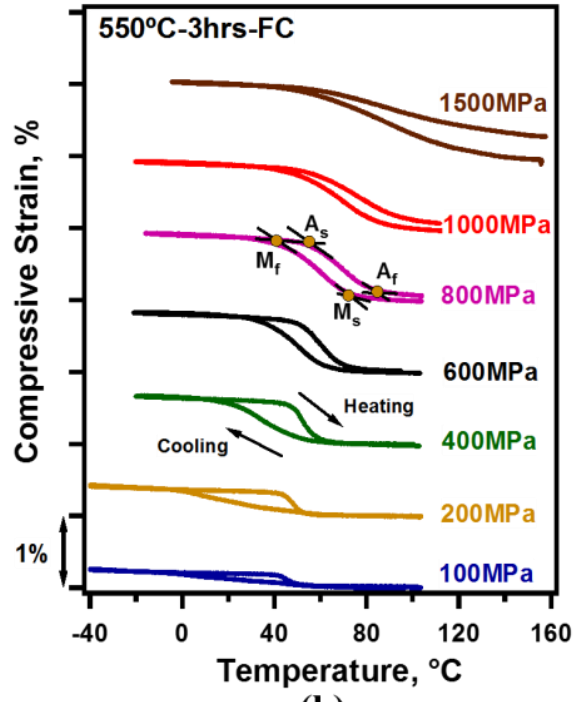

(b)

Figure 2. Thermal cycling under compressive stress results of a) $550^{\circ} \mathrm{C}-\mathrm{WQ}$ and b) $550^{\circ} \mathrm{C}-\mathrm{FC}$ samples after $3 \mathrm{~h}$ aging

Figure 3 shows the stress-strain results of $550^{\circ} \mathrm{C}-\mathrm{WQ}$ [20] and $550^{\circ} \mathrm{C}-\mathrm{FC}$ samples. $550^{\circ} \mathrm{C}$-WQ sample was loaded to a transformation strain of $2 \%$ at $-90{ }^{\circ} \mathrm{C}$ (below $\mathrm{M}_{\mathrm{f}}$ ), and retained strain of $0.5 \%$ was observed upon unloading. After heating the sample above $A_{f}$, the retained strain was fully recovered which is called shape memory effect. Superelasticity was observed with applying stress above $A_{f}$ followed by unloading. The $550^{\circ} \mathrm{C}$-WQ sample showed recoverable superelasticity at $-30{ }^{\circ} \mathrm{C}$ while it had only $0.22 \%$ irrecoverable strain upon loading to $4 \%$ strain till $2000 \mathrm{MPa}$ at $40{ }^{\circ} \mathrm{C}$. Figure 3 demonstrates that Ti-54at.\% $\mathrm{Ni}$ alloys have very high strength without being subjected to thermomechanical treatments.

Figure $3 \mathrm{~b}$ shows the superelastic curves of $550^{\circ} \mathrm{C}-\mathrm{FC}$ sample at selected temperatures $(50,70$ and 140 ${ }^{\circ} \mathrm{C}$ ). While the critical stress which is the stress level for the onset of transformation into martensite was $1030 \mathrm{MPa}$ at $40{ }^{\circ} \mathrm{C}$ for $550^{\circ} \mathrm{C}$-WQ sample, it was $408 \mathrm{MPa}$ at $50{ }^{\circ} \mathrm{C}$ for $550^{\circ} \mathrm{C}$-FC sample. When the operating temperature was increased to $70^{\circ} \mathrm{C}$, the critical stress was increased to $669 \mathrm{MPa}$ for $550^{\circ} \mathrm{C}$ FC sample. It should also be noted that $550^{\circ} \mathrm{C}$-FC sample shows almost full recovery with loading up to $2 \%$ strain at $70{ }^{\circ} \mathrm{C}$. Figure 3 also shows that the temperature influences the critical stress. When the test temperature increases, high critical stress is acquired. The critical stress was $485 \mathrm{MPa}$ at $-30{ }^{\circ} \mathrm{C}$ while it was $1029 \mathrm{MPa}$ at $40^{\circ} \mathrm{C}$ for $550^{\circ} \mathrm{C}$-WQ sample. 


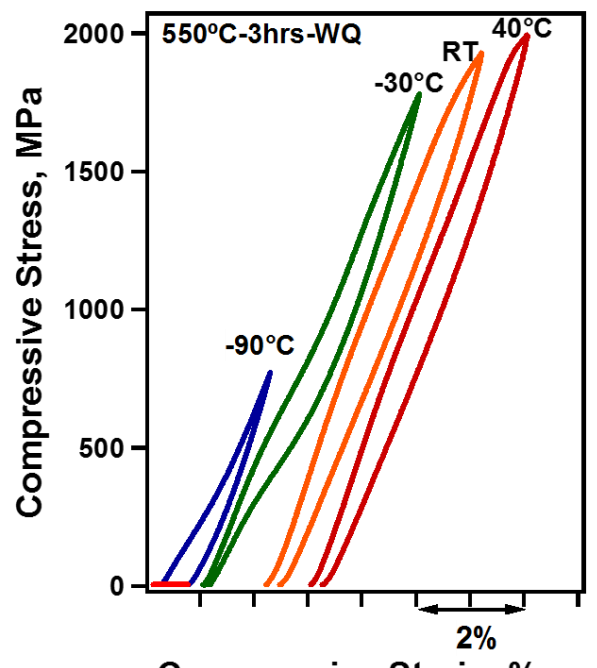

Compressive Strain, \%

(a)

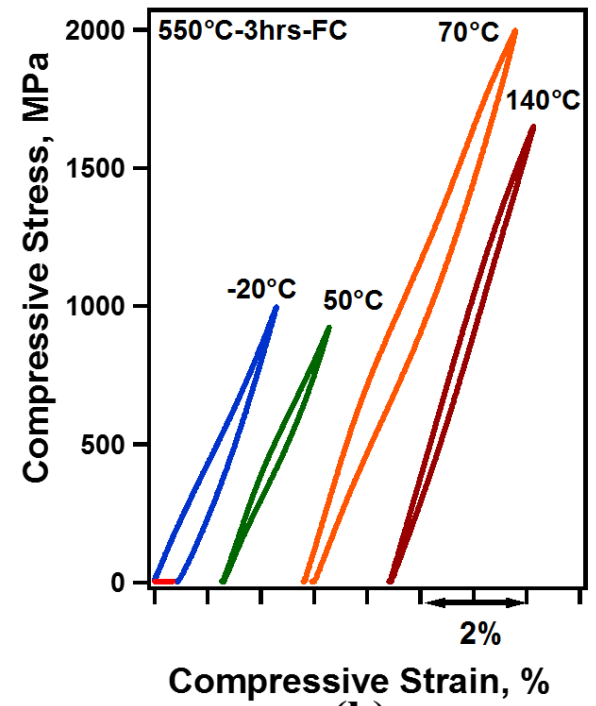

(b)

Figure 3. Stress - strain responses of Ti-54at. $\% \mathrm{Ni}$ for a) $550^{\circ} \mathrm{C}-\mathrm{WQ}$ and b) $550^{\circ} \mathrm{C}$-FC samples

Figure 4a shows the transformation strains as a function of compressive stress obtained from thermal cycling under stress responses for aged samples (Figure 2). Upon application of stress, favored martensite variants can be formed [21]. Initially, the transformation strains increased with stress due to the formation of increased volume fraction of favored martensite variants and then they saturated. In the $550^{\circ} \mathrm{C}-\mathrm{WQ}$ sample, the transformation strain initially increased with stress up to $1000 \mathrm{MPa}$, and then saturated. The maximum transformation strain of $1.08 \%$ was obtained under $1000 \mathrm{MPa}$ in the $550^{\circ} \mathrm{C}$ WQ sample while it was $0.82 \%$ for $550^{\circ} \mathrm{C}$-FC sample. During furnace cooling, the specimen was subjected to lower temperature for a long time, resulting in the growth of the precipitates. It should be noted that according to the TEM results shown in Figure 1, the density of precipitates was higher in the $550^{\circ} \mathrm{C}$-FC sample compared to $550^{\circ} \mathrm{C}$-WQ sample. Due to the high density of precipitates, the distance between the particles was small and could prevent the transformation. Consequently, less transformation strain was observed for FC sample.

Figure $4 \mathrm{~b}$ shows the effect of cooling rate on thermal hysteresis and irrecoverable strain responses as a function of applied compressive stress of Ti-54at.\%Ni alloys. For $550^{\circ} \mathrm{C}-\mathrm{WQ}$ sample, the thermal hysteresis did not change much initially and then decreased rapidly after $400 \mathrm{MPa}$ stress level. After high stress level of $800 \mathrm{MPa}$, the thermal hysteresis saturated. For $550^{\circ} \mathrm{C}-\mathrm{FC}$ sample, the thermal hysteresis decreased drastically at low stress region, and then saturated till $1000 \mathrm{MPa}$ stress level. After this stress level, hysteresis rapidly increased due to the increased irrecoverable strain.

In Figure $4 \mathrm{c}, \mathrm{M}_{\mathrm{s}}$ of $550^{\circ} \mathrm{C}-\mathrm{WQ}$ and $550^{\circ} \mathrm{C}$-FC samples as a function of applied stress that were obtained from thermal cycling under stress responses shown in Figure 2. The relation between temperature and stress parameters has been expressed in a Clausius-Clapeyron $(\mathrm{Cs}-\mathrm{Cl})$ equation that is formulated as [22]

$$
\frac{\Delta \sigma}{\Delta T}=-\frac{\Delta H}{T_{0} \varepsilon_{t}}
$$

where $\Delta \sigma$ is the difference between critical stresses, $\varepsilon_{t}$ is the transformation strain, $\Delta H$ is the transformation enthalpy, $\Delta T$ is the temperature difference, and $T_{0}$ is the equilibrium temperature. The $\mathrm{M}_{\mathrm{s}}$ temperature increases linearly with stress following the Clausius-Clapeyron (Cs-Cl) relationship. Cs$\mathrm{Cl}$ slopes were $13.2 \mathrm{MPa} /{ }^{\circ} \mathrm{C}$ and $16.9 \mathrm{MPa} /{ }^{\circ} \mathrm{C}$ for WQ and $\mathrm{FC}$ samples, respectively. The $\mathrm{FC}$ sample has higher $\mathrm{Cs}-\mathrm{Cl}$ slope that can be attributed to the lower transformation strain. In this study, the $\mathrm{Cs}-\mathrm{Cl}$ 
slope for martensite was also high when compared to the Cs-Cl slope of near equiatomic NiTi alloys. For comparison, the Cs-Cl slope was $12 \mathrm{MPa} /{ }^{\circ} \mathrm{C}$ in compression for Ni50Ti50 polycrystalline alloys [23]. The increase in $\mathrm{M}_{\mathrm{s}}$ temperatures with decreased cooling rate could clearly be seen in the Figure 4c. The $\mathrm{M}_{\mathrm{s}}$ temperatures were $-41{ }^{\circ} \mathrm{C}$ and $55^{\circ} \mathrm{C}$ for the WQ and FC samples, respectively under 200 MPa stress. Figure $4 \mathrm{c}$ also shows that TTs can be tailored by applying different cooling rates in Ti54at.\%Ni alloys.

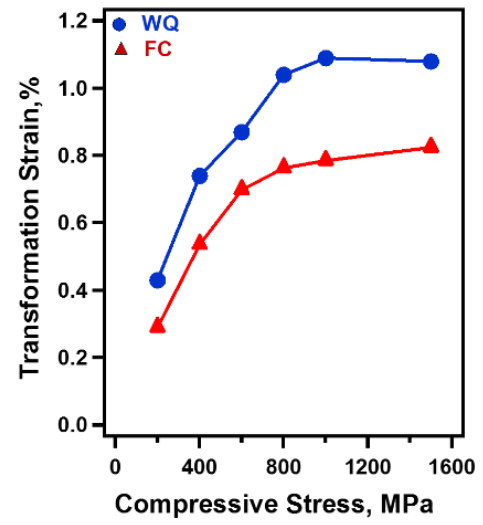

(a)

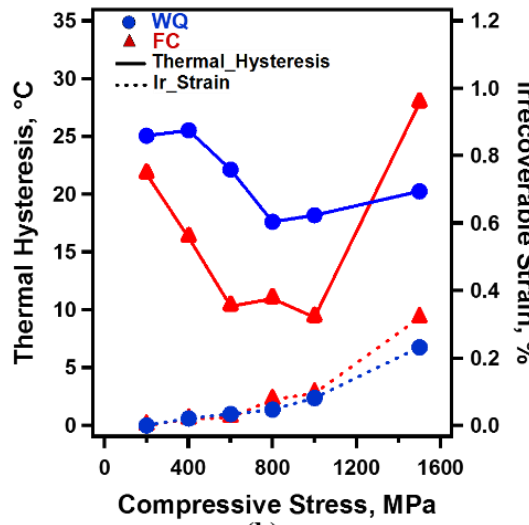

(b)

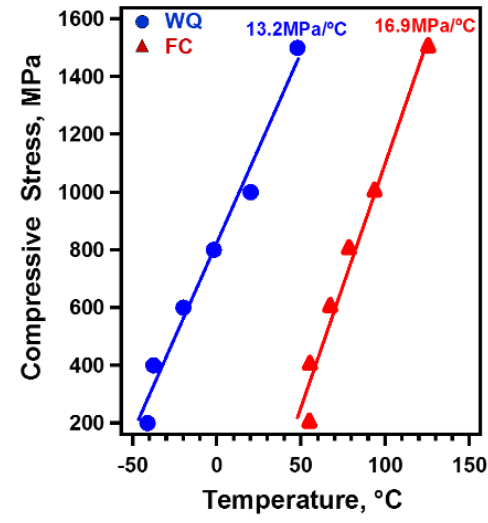

(c)

Figure 4. a) Transformation strain, b) thermal hysteresis and irrecoverable strain, c) $M_{s}$ values as a function of applied stress.

\section{CONCLUSION}

This paper investigates the cooling rate effects on the shape memory behavior of Ti-54at.\%Ni alloys. It is shown that mechanical and shape memory properties of Ti-54at.\% Ni alloys were highly cooling rate and applied stress dependent. $\mathrm{A}_{\mathrm{s}}$ transformation temperatures were increased from $-39{ }^{\circ} \mathrm{C}$ to $32{ }^{\circ} \mathrm{C}$ with a decrease in cooling rate after aging at $550^{\circ} \mathrm{C}$. The shape memory behavior of Ti-54at.\% Ni alloys were investigated under compression and it has been shown that they have low transformation strain but very high strength, very narrow temperature hysteresis and dramatic change in shape memory behavior with stress. The maximum transformation strain of $1.08 \%$ was obtained under $1000 \mathrm{MPa}$ in the WQ sample while it was $0.82 \%$ for $\mathrm{FC}$ sample. Cs-Cl slopes were $13.2 \mathrm{MPa} /{ }^{\circ} \mathrm{C}$ and $16.9 \mathrm{MPa} /{ }^{\circ} \mathrm{C}$ for WQ and $\mathrm{FC}$ samples, respectively.

\section{ACKNOWLEDGEMENTS}

The author wish to gratefully acknowledge the financial support provided for this study by Anadolu University (Grant no. BAP-1505F247). The author gratefully acknowledges Dr. M. Nagasako for TEM results.

\section{REFERENCES}

[1] Shabalovskaya SA. Surface, corrosion and biocompatibility aspects of Nitinol as an implant material. Bio-Medical Materials and Engineering, 2002; 12(1): p. 69-109.

[2] Otsuka K, Ren X. Physical metallurgy of Ti-Ni-based shape memory alloys. Progress in materials science, 2005; 50(5): p. 511-678.

[3] Otsuka K, Wayman C. Mechanism of shape memory effect and superelasticity. Shape memory materials, 1998; p. 27-49. 
[4] Kurumada M, et al., TEM study of early Ni 4 Ti 3 precipitation and R-phase in Ni-rich NiTi nanoparticles. Scripta materialia, 2004; 50(11): p. 1413-1416.

[5] Hornbogen E. Shape Memory Alloys, in Advanced Structural and Functional Materials: Proceedings of an International Seminar Organized by Deutsche Forschungsanstalt für Luft- und Raumfahrt (DLR), Köln, June 1991, W.G.J. Bunk, Editor, 1991, Springer Berlin Heidelberg: Berlin, Heidelberg. p. 133163.

[6] Prokofiev E. et al. Phase transformations and functional properties of NiTi alloy with ultrafinegrained structure. in Materials Science Forum. 2011; Trans Tech Publ.

[7] Otsuka K, Sawamura T, Shimizu K. Crystal structure and internal defects of equiatomic TiNi martensite. Physica status solidi (a), 1971; 5(2): p. 457-470.

[8] Knowles K, Smith D. The crystallography of the martensitic transformation in equiatomic nickeltitanium. Acta Metallurgica, 1981; 29(1): p. 101-110.

[9] Carroll M, Somsen C, Eggeler G. Multiple-step martensitic transformations in Ni-rich NiTi shape memory alloys. Scripta Materialia, 2004; 50(2): p. 187-192.

[10] Šittner P, Lukáš P, Novák V, Daymond MR, Swallowe GM. In situ neutron diffraction studies of martensitic transformations in NiTi polycrystals under tension and compression stress. Materials Science and Engineering: A, 2004; 378(1-2): p. 97-104.

[11] Mahesh K, Fernandes FB, Silva RJ. Ageing effects on phase transformations in NiTi alloys. in European Symposium on Martensitic Transformations, 2009. EDP Sciences.

[12] Motemani Y, Nili-Amadabadi M, Tan MJ, Bornapour M, Rayagah Sh. Effect of cooling rate on the phase transformation behavior and mechanical properties of Ni-rich NiTi shape memory alloy. Journal of Alloys and Compounds, 2009; 469(1-2): p. 164-168.

[13] Nishida M, Wayman C, Honma T. Precipitation processes in near-equiatomic TiNi shape memory alloys. Metallurgical and Materials Transactions A, 1986; 17(9): p. 1505-1515.

[14] Kainuma R, Matsumoto M, Honma T. Metallographic Study of Precipitation Processes in NickelRich TiNi Alloys. Bull. Res. Inst. Miner. Dressing Metall., 1987; 43(2): p. 149-158.

[15] Khalil-Allafi J, Amin-Ahmadi B. Multiple-step martensitic transformations in the Ni51Ti49 single crystal. Journal of materials science, 2010; 45(23): p. 6440-6445.

[16] Eggeler G, Khalil-Allafi J, Gollerthan, S. Somsen C, Schmah W, Sheptyakov D, On the effect of aging on martensitic transformations in Ni-rich NiTi shape memory alloys. Smart materials and structures, 2005; 14(5): p. S186.

[17] Dlouhy A, Khalil-Allafi J, Eggeler G. Multiple-step martensitic transformations in Ni-rich NiTi alloys--an in-situ transmission electron microscopy investigation. Philosophical Magazine, 2003; 83(3): p. 339-363.

[18] Khalil-Allafi J, Eggeler G, Schmahl WW, Sheptyakov D. Quantitative phase analysis in microstructures which display multiple step martensitic transformations in Ni-rich NiTi shape memory alloys. Materials Science and Engineering: A, 2006; 438-440(0): p. 593-596. 
Kaya / Anadolu Univ. J. of Sci. and Technology A - Appl. Sci. and Eng. 18 (2) - 2017

[19] Karaca H, Kaya I, Tobe H, Chumlyakov Y. Shape memory behavior of high strength Ni 54 Ti 46 alloys. Materials Science and Engineering: A, 2013; 580: p. 66-70.

[20] Kaya I, Tobe H, Karaca H, Chumlyakov Y. Effects of aging on the shape memory and superelasticity behavior of ultra-high strength Ni 54 Ti 46 alloys under compression. Materials Science and Engineering: A, 2016; 678: p. 93-100.

[21] Elahinia M. Shape Memory Alloy Actuators: Design, Fabrication and Experimental Evaluation, 2015; John Wiley \& Sons.

[22] Wollants P, Bonte M De, Roos J. Thermodynamic analysis of the stress-induced martensitictransformation in a single-crystal. Zeitschrift fur metallkunde, 1979; 70(2): p. 113-117.

[23] Orgéas L, Favier D. Stress-induced martensitic transformation of a NiTi alloy in isothermal shear, tension and compression. Acta Materialia, 1998; 46(15): p. 5579-5591. 